\title{
Laboratory Characterization of Asphalt Mixtures Containing Steel Slag
}

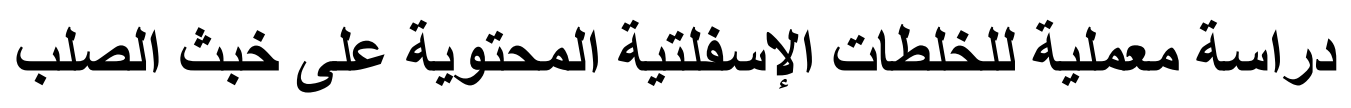

M. Shiha ${ }^{1}$, A. Gabr ${ }^{2}$, and S. El-Badawy ${ }^{3}$

${ }^{1}$ Graduate Student, ${ }^{2}$ Assistant Professor, ${ }^{3}$ Associate Professor, Public Works Engineering Department, Faculty of Engineering, Mansoura University, Egypt.

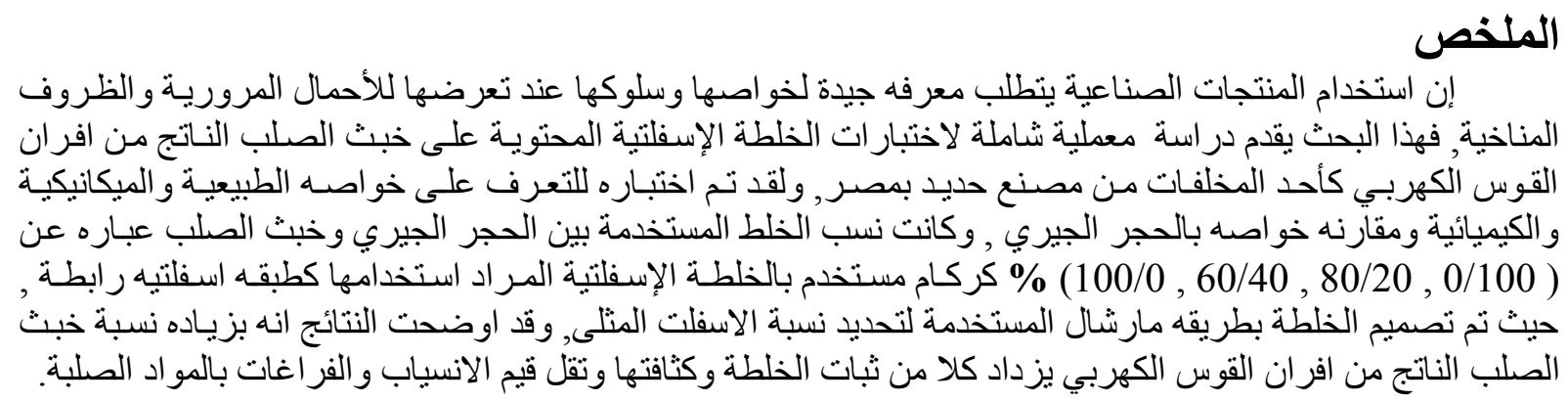

\section{Abstract}

The use of industrial by-products needs better understanding of their characteristics and behavior when subjected to traffic loading and environmental conditions. This paper presents a comprehensive laboratory characterization testing of asphalt mixtures containing steel slag. Electric Arc Furnace Steel Slag (EAFS) products were chosen as one of the most significant types of non-hazardous metallurgical waste, which were sourced from a steel factory in Egypt. The routine tests were conducted on EAFS materials to examine the physical, mechanical, and chemical properties, which were compared with the virgin aggregate (limestone). Blends of limestone aggregates/EAFS with percentages of 100/0, 80/20,60/40, and 0/100\% were selected to be employed as binder course layer. Asphalt mixtures were designed by Marshall method to find the optimum binder content. Test results showed that as the EAFS percentage in the mix increased, both the stability and density of the mixes increased. In addition, the flow and voids in mineral aggregates (VMA) were found to decrease with an increase in the EAFS content.

\section{Keywords}

Electric Arc Furnace Steel Slag, characterization, Marshall, VMA, stability, flow.

\section{Introduction}

Slags are used in many applications, such as road construction aggregate, concrete, railway ballast, cement, mineral wool, etc. The old Romans used slag from furnaces for construction of the Roman roads in the Sussex District in England (Emery, 1984). Since the first half of the 19th century, USA have used slag in construction of roads (as bases and in bituminous mixtures), railways, and in cement manufacturing (Lewis, 1982).

EAFS is a by-product of the steel manufacturing process using high-power electric arcs, instead of gaseous fuels, to produce heat which melts recycled steel scrap and converts it to a high-quality steel (see Figure 1). EAFS products are recommended for use in Asphalt Concrete (AC) mixes as one of the non-hazardous metallurgical waste. Proper processing of steel slag and special quality control procedures are extremely important in selecting steel slag for use in HMA mixes.

Steel slag can be processed into coarse or fine aggregate material for use in dense-graded and open-graded HMA pavements (Norton, 1979) and in cold mixes or surface treatment applications (Noureldin, and McDaniel, 1990). Some types of slag are produced with high 
percentages of free lime and magnesium oxides, which cause hydration and expansion in humid environments (JEGEL, 1993). The free lime in steel slags can combine with water to produce calcium hydroxide $(\mathrm{Ca}(\mathrm{OH}) 2)$ solution. Upon exposure to atmospheric carbon dioxide, calcite $(\mathrm{CaCO} 3)$ may precipitate in the form of surficial tufa and powdery sediment in surface water. Tufa precipitates have been found to block drainage paths in pavement systems (Shatnawi et al., 2008). The free lime hydrates rapidly and can cause large volume changes (expansion) over a relatively short period of time (weeks), which may result in cracking of asphalt (Tarco, 2000).

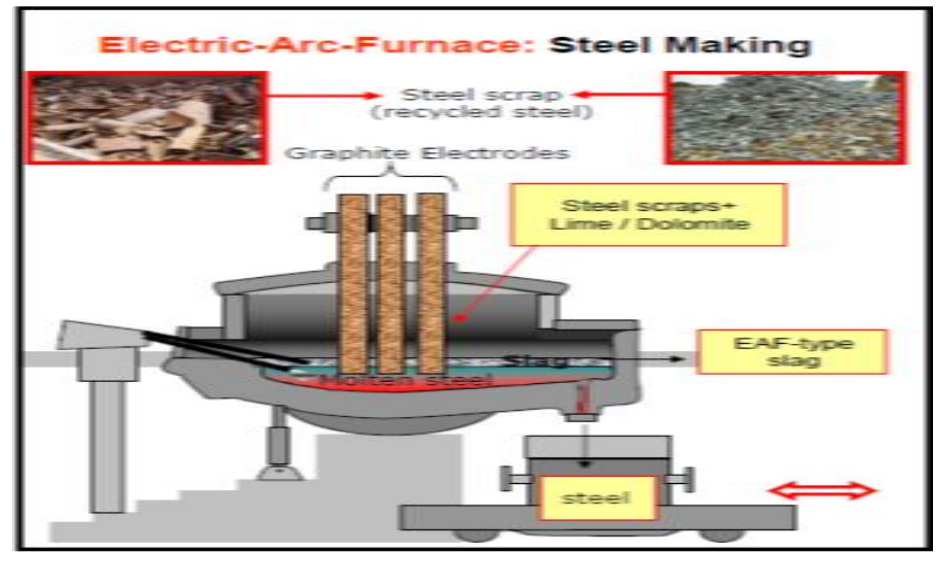

Figure 1. Schematic representation of the electric-arc-furnace steel making process (Yildirim and Prezzi, 2009).

Although, many of researchers have used steel slag in HMA, few researchers have used it in binder course layer, which are the focus of this research. Thus, the main objective of this study is to characterize the physical, chemical, and mechanical properties of the EAFS for application as HMA binder course layer

\section{Literature Review}

Numerous studies have been conducted on laboratory characterization of AC containing EAFS; some pertinent studies are presented in the following.

Khan et al. (2002) evaluated asphalt mixtures containing steel slag with percentage of $48 \%$ of total weight of virgin aggregates for wearing course asphalt mix. For base course asphalt mix, they used two different mixes with two different percentages of steel slag of $100 \%$ and $61 \%$ of the total weight of virgin aggregates.
They concluded that the use of steel slag aggregate as a base or in asphalt layers minimized the use of natural aggregates, and hence can reserve the natural resources. They concluded also that the use of steel slag aggregate in asphalt mixes improve the resistance of surface skidding and increase the pavement fatigue.

Asi et al. (2007) replaced the limestone aggregates in asphalt mixes by the steel slag with percentages of $0 \%$, $25 \%, 50 \%, 75 \%$, and $100 \%$ of the total weight of aggregates. They also investigated the toxicity, chemical and physical properties of the steel slag. The effectiveness of the steel slag aggregate was characterized by a comprehensive testing i.e., indirect tensile strength test, resilient modulus test, wheel track test, creep test, and stripping resistance test. Asi et al. (2007) concluded that steel slag aggregate can be used in $\mathrm{AC}$ mixes, since 
its properties met both Superpave properties and Jordanian standards. They also found that replacing up to $75 \%$ of the limestone coarse aggregate by steel slag aggregate improved the mechanical properties of the AC mixes

Shatnawi, et al. (2008) compared the use of $100 \%$ steel slag in wearing course mix with the conventional wearing course mix using dense graded limestone at the same grading and bitumen contents. Shatnawi, et al., 2008 concluded that steel slag mix yielded higher stability and higher resistance to rutting.

Fistrić, et al. (2010) investigated $75 \%$ steel slag aggregate with $25 \%$ limestone rock aggregate to be used in $\mathrm{AC}$ mixes. Results showed that the steel slag produced from water-cooled process yielded good resistance to permanent deformation, high stability with good flow properties and high resilient modulus. However, authors haven't compared the results of $75 \%$ steel slag mix with conventional asphalt mix.

Louzi, (2012) used steel slag in the AC mixtures with different percentages $(15,30$ and $45 \%)$ of the total weight of coarse aggregates. Fatigue, indirect tensile strength, loss of indirect tensile strength and the resilient modulus laboratory tests were performed on all hot mixes. Louzi, (2012) concluded that steel slag improved the properties of asphalt mixtures in terms of fatigue life, indirect tensile strength, resilient modulus and stability.

Hainin, et al. (2012) compared the use of steel slag with two different nominal maximum sizes in $\mathrm{AC}$ mixes with the conventional AC mix. The Marshall Mix design system was used for samples preparation in accordance with Malaysian specifications. Samples of AC mixes were subjected to the resilient modulus test and creep test. Hainin et al (2012) concluded that steel slag mixes showed lower permanent deformation than conventional asphalt mixes.

\section{Experimental Program}

A schematic representation of the experimental program conducted in this research is shown in Figure 2. The laboratory work was divided into three phases as follows: Phase I included collection and characterization of the limestone aggregates, bitumen and EAFS aggregates. In phase II, four AC mixes were characterized. The percentage of EAFS in the investigated mixes was 0 , and $100 \%$ of total weight of aggregates and 60, and $80 \%$ of coarse aggregate weight.

Phase III, included the evaluation and analysis of the four different mixes.

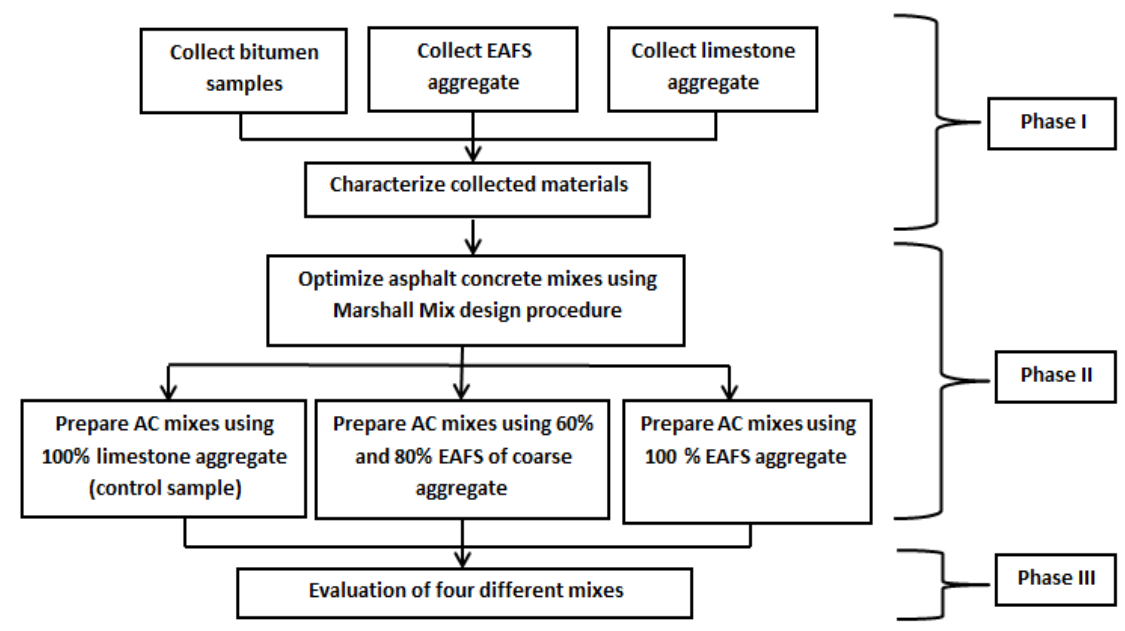

Figure 2. Flow chart of the experimental program 


\section{Materials Used}

\section{Bitumen}

There are three sources of bitumen in Egypt; Suez Oil Processing Co (SOPC), Alexandria Petroleum Co (APC), and Amreya Petroleum Refining Co (APRC). In this study, bitumen from only one source, which is the APRC was used. Penetration, specific gravity, softening point, flash point, and kinematic viscosity tests were conducted on the selected bitumen. Table 1 presents a summary of the results of the routine tests performed on the bitumen. It is noted from the table that all the bitumen properties comply with the Egyptian standards (ECP, 2008).

Table 1. Physical properties of the asphalt cement used in the study.

\begin{tabular}{|c|c|c|c|}
\hline Properties & Standard & $\begin{array}{c}\text { (ECP-2008) } \\
\text { Limits }\end{array}$ & $\begin{array}{c}\text { Measured } \\
\text { values }\end{array}$ \\
\hline Specific gravity & (ASTM D 70) & N/A & 1.023 \\
\hline Penetration $(* 10 ~ \mathbf{~ m m})$ & (AASHTO T49) & $60-70$ & 62 \\
\hline Softening point $\left({ }^{\circ} \mathrm{C}\right)$ & (AASHTO T53) & $\mathbf{4 5 - 5 5}{ }^{\circ} \mathrm{C}$ & 52 \\
\hline kinematic viscosity $(\mathbf{c s t} / \mathbf{s})$ & (AASHTO T 201) & minimum 320cst/s & 374 \\
\hline Flash point $\left({ }^{\circ} \mathrm{C}\right)$ & (AASHTO T48) & minimum $250{ }^{\circ} \mathrm{C}$ & $\mathbf{2 7 0}^{\circ} \mathrm{C}$ \\
\hline
\end{tabular}

N/A, Not Applicable.

\section{$>\quad$ Limestone and steel slag aggregates Gradation}

Gradation of limestone and EAFS aggregates were fractionated to lie between the specification limits of the binder course (3d) in accordance with the Egyptian Specifications (ECP, 2008) as shown in Figure 3.

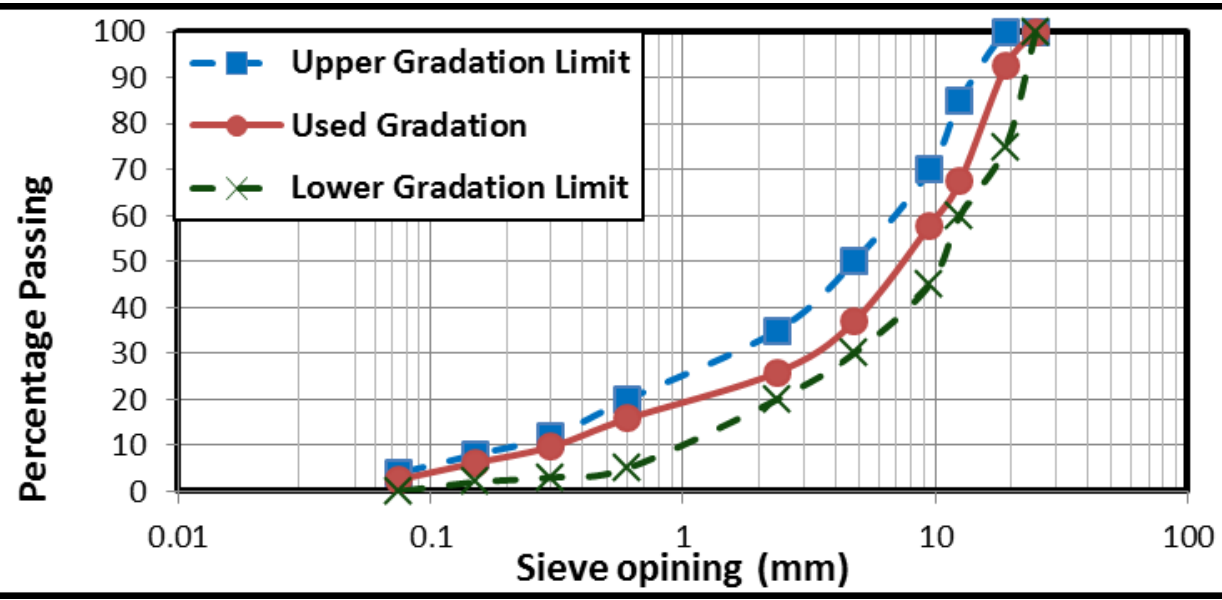

Figure 3. Job Mix Formula gradation for aggregates compared with the specification limits 


\section{$>$ Physical and mechanical properties}

Table 2 lists a summary of the physical and mechanical properties of EAFS and limestone aggregates. EAFS are angular in shape and have a rough surface texture compared to the limestone aggregate. EAFS showed higher bulk specific gravity, lower water absorption, and higher adhesion with bitumen compared with the limestone. Better abrasion resistance and soundness were noticed for the EAFS. The data in Table 2 showed that EAFS and limestone properties are within the specifications limits (ECP, 2008).

\section{$>\quad$ Chemical properties}

The chemical composition of the EAFS is usually expressed in terms of simple oxides calculated from elemental analysis determined by x-ray fluorescence. Table 3 presents the percentage of compounds exist in the investigated steel slag from the electric arc furnace. It consists primarily of $\mathrm{CaO}, \mathrm{MgO}, \mathrm{SiO} 2$, and $\mathrm{FeO}$. Of more importance is the mineralogical form of the slag, which is highly dependent on the rate of slag cooling in the steel-making process (Contra Steel Co, 2014).

EAFS contains free calcium and magnesium oxides with percentages of 37.9 and 7.53, respectively, which are not completely consumed in the steel slag. The hydration of free lime and magnesia in contact with moisture is largely responsible for the expansive nature of most steel slags. This needs appropriate processing in construction to prevent asphalt cracks as found in the literature.

\section{Methods, Results, and Discussion}

\section{$>$ Preparation of Marshall Specimens}

Marshall Specimens were prepared and tested according to the AASHTO T 245. Aggregates and bitumen were heated at a temperature of $140^{\circ} \mathrm{C}$. The heated aggregates and the asphalt cement were mixed thoroughly in the mixer. The maximum specific gravity, Gmm of the loose mix was determined by Rice test in accordance with the AASHTO T 209 for all mixes. Fifteen specimens in total at different binder contents ranged from 3.5 to $5.5 \%$ were compacted by Marshall's hammer with 75 blows on each side to simulate heavy traffic. Specimens were extracted from the molds and kept at ambient temperature for one day. Bulk specific gravity, Gmb was measured for all mixes; summary of Gmb charts are shown in Figure 4. Specimens were kept in a water bath at $60^{\circ} \mathrm{C}$ for 30 minutes, and then tested in Marshall's apparatus to obtain the stability and flow. 
Table 2. Physical and mechanical properties of the limestone and slag aggregate used in the study.

\begin{tabular}{|c|c|c|c|c|}
\hline Property & Standard & $\begin{array}{l}\text { (ECP-2008) } \\
\text { Limits }\end{array}$ & Limestone Aggregate & EAFS \\
\hline Flat/elongated (1:5 ratio), \% & (ASTM D 4791) & $10 \% \max$ & $\mathbf{0} \%$ & $0 \%$ \\
\hline Sand equivalent, \% & (ASTM D2419) & $45 \% \min$ & $58 \%$ & $88 \%$ \\
\hline Coarse aggregate specific gravity & (AASHTO T 84) & N/A & 2.535 & 3.300 \\
\hline Coarse aggregate absorption, $\%$ & (AASHTO T 84) & $5 \% \max$ & $2.27 \%$ & $1.38 \%$ \\
\hline Fine aggregate specific gravity & (AASHTO T 85) & N/A & 2.611 & 3.356 \\
\hline Fine aggregate absorption $\%$ & (AASHTO T 85) & $5 \% \max$ & $3.45 \%$ & $2.16 \%$ \\
\hline Clay lumps and friable particles, $\%$ & (AASHTO T 112) & $1 \% \max$ & $0.14 \%$ & $\mathbf{0 \%}$ \\
\hline Stripping Value, \% & (AASHTO T 182) & $95 \% \min$ & $>95 \%$ & $>95 \%$ \\
\hline Abrasion loss (500 rev), \% & (AASHTO T 96) & $40 \% \max$ & $25.9 \%$ & $21.8 \%$ \\
\hline $\begin{array}{l}\text { Soundness by (Mg SO4), \% } \\
\text { Soundness by (Na2 SO4), \% }\end{array}$ & $\begin{array}{l}(\text { AASHTO T 104) } \\
(\text { AASHTO T 104) }\end{array}$ & $\begin{array}{l}18 \% \max \\
12 \% \max \end{array}$ & $\begin{array}{l}3.50 \% \\
2.40 \%\end{array}$ & $\begin{array}{l}2.10 \% \\
1.82 \%\end{array}$ \\
\hline
\end{tabular}

N/A, Not Applicable.

Table 3.The chemical properties of EAFS in this study (Contra Steel Co, 2014)

\begin{tabular}{|l|c|}
\hline Component & Percentage \% \\
\hline Free Lime $(\mathrm{CaO})$ & 37.9 \\
\hline Silicon dioxide $(\mathrm{SiO} 2)$ & 21.99 \\
\hline Manganese oxide $(\mathrm{MnO})$ & 2.24 \\
\hline Magnesium oxide $(\mathrm{MgO})$ & 7.53 \\
\hline Aluminum oxide $(\mathrm{Al} 2 \mathrm{O} 3)$ & 7.9 \\
\hline T Fe & 22.78 \\
\hline
\end{tabular}

Percentage of air voids, Va\%, VMA, and voids filled with asphalt (VFA) were calculated from the volumetric properties of the specimens. The OBC was determined based on the Marshall design charts (Bulk density, Marshall stability and Va). The OBC values for the different mixes were ranged from 4.5 to $4.85 \%$. Marshall flow, VMA and VFA were checked based on the resulted OBC. Table 4 summarizes the Marshall properties for the different mixes. Marshall plots and the relationship between rigidity, which is the ratio of the stability over flow, and the percent of asphalt in the mix for the mixes containing different percentages of slag are shown in Figures 4 through 10. 
Table 4. Marshall Properties for the different mixes.

\begin{tabular}{|l|c|c|c|c|}
\hline & $\begin{array}{c}\text { Control } \\
\text { sample }\end{array}$ & $\begin{array}{c}\text { 60\% EAFS } \\
\text { of C.A* }\end{array}$ & $\begin{array}{c}\text { 80\% EAFS } \\
\text { of C.A* }\end{array}$ & $\begin{array}{c}100 \% \\
\text { EAFS }\end{array}$ \\
\hline OBC \% & 4.85 & 4.73 & 4.62 & 4.50 \\
\hline Stability(Kg) & 1100 & 1440 & 1570 & 1930 \\
\hline Bulk density & 2.321 & 2.598 & 2.675 & 3.038 \\
\hline Air voids\% & 4.9 & 4.4 & 4.20 & 3.90 \\
\hline Flow(mm) & 3.65 & 3.5 & 3.30 & 2.90 \\
\hline Rigidity(Kg/mm) & 301 & 415 & 476 & 666 \\
\hline VMA (\%) & 15.4 & 15.1 & 14.6 & 14.3 \\
\hline VFA (\%) & 68.0 & 70.0 & 72.0 & 72.9 \\
\hline
\end{tabular}

\section{Analysis of Marshall Results}

Figures 4 through 7 show the bulk density, stability, flow and rigidity values results for all mixes. It is clear from the figures that the $100 \%$ EAFS mix had the highest bulk density, stability and rigidity compared with the other mixes. It is believed that the reason for this may be due to the high specific gravity and low Los Angeles Abrasion values of the EAFS, compared to limestone aggregates as given before in Table 2. ECP (2008) restricts the use of binder course asphalt mixes for heavy traffic roads that has a rigidity value greater than $700 \mathrm{~kg} / \mathrm{mm}$ however all mixes prepared at OBC met this limit as presented in Figure 7. Slight decrease in the flow values with the increase of EAFS percentage in the mix was noticed as shown in Figure 6. Moreover, all specimens at OBC were within limits of flow of $2-4 \mathrm{~mm}$ for heavily trafficked roads as recommended by ECP, 2008.
VMA values at OBC were also within specification limits as presented in Figure 9 except the $100 \%$ and $80 \%$ EAFS mixes. These mixes had a VMA value of less than $15 \%$. However, the Asphalt Institute recommended that minimum, VMA for aggregates with nominal maximum size of $3 / 4$ " is $14 \%$.

The percentages of $\mathrm{Va}$, and VMA were found to decrease with the increase of EAFS percentage (Figures 8 and 9). It is believed that the reason for this is that EAFS form more angular in shape and the effect of aggregate interlock may increase the internal friction within the asphalt, which increase $\mathrm{Gmm}$ with the increase of EAFS (e.g., Topal and Sengoz, 2006; Park and Lee, 2002). In contrast, Figure 10 shows that the VFA increased with the increase of EAFS percentage. The reason for this that the steel slag aggregate had low absorption value.

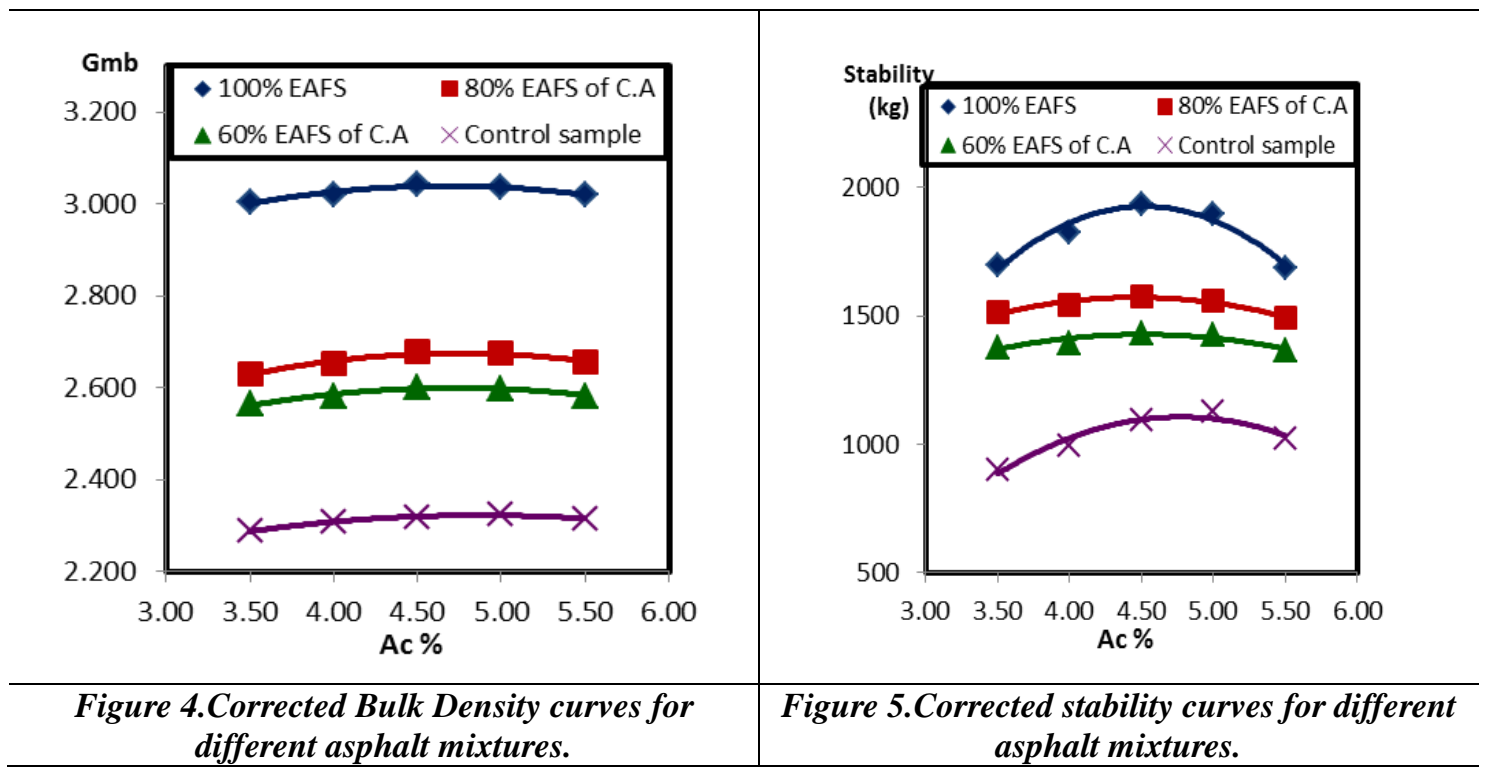




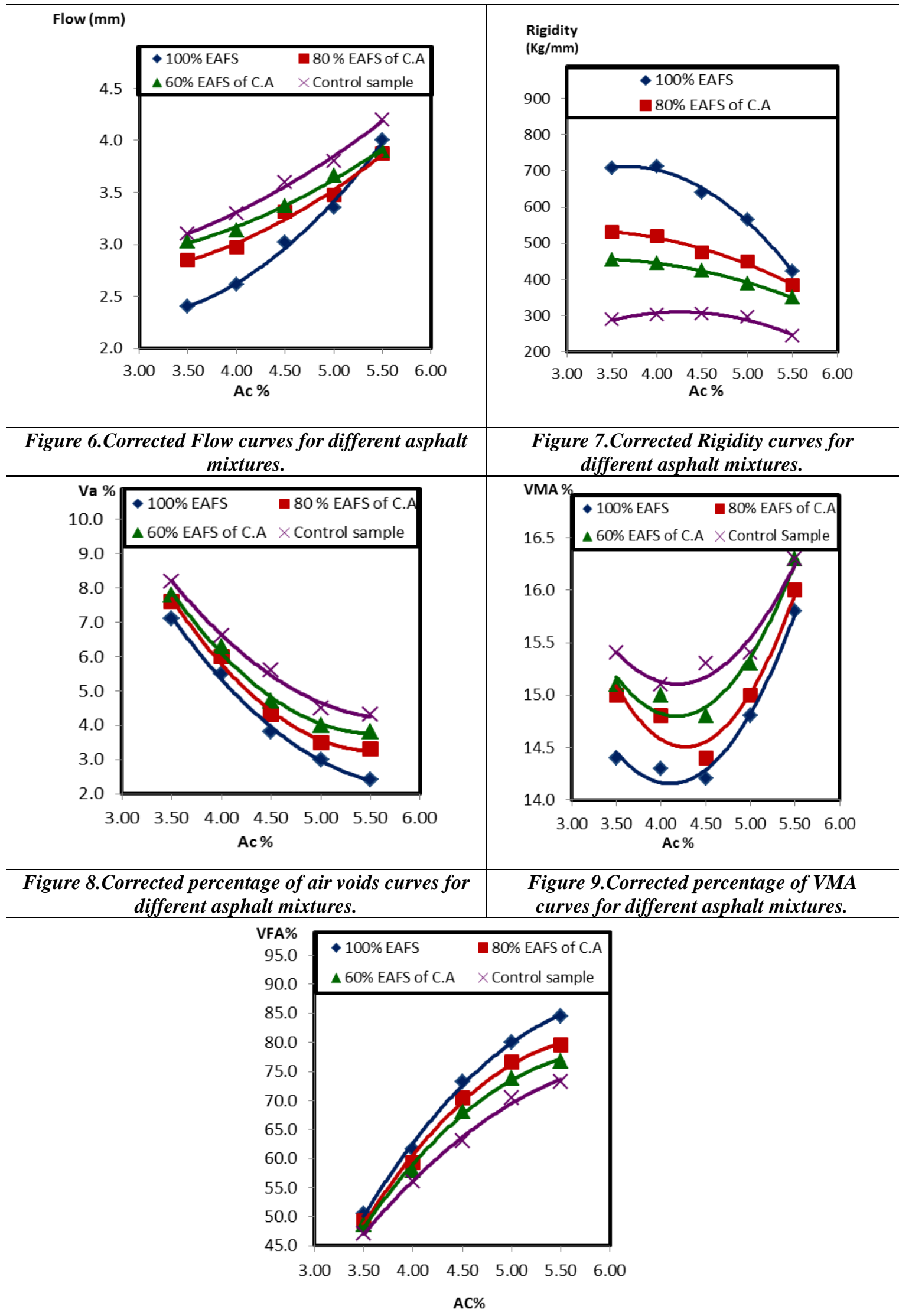




\section{Conclusions}

- The engineering and ecological properties of steel slag aggregate have been accepted in many countries worldwide including Egypt and EAFS was widely utilized in the construction of pavements.

- The results of this study suggest that utilization of steel slag aggregate can benefit the environment and at the same time reduce the amount of limestone and dolomite application in highway construction.

- Research results showed that EAFS had particle properties such as high bulk specific gravity, low Los Angeles Abrasion values, low water absorption and high adhesion with bitumen that can improve the performance of asphalt concrete hot mixes.

- $\quad$ Test results showed that as the EAFS percentage in the mix increased, both the stability and density of the mixes increased. In addition, the flow and VMA decreased with an increase in the EAFS content.

- Further research in particular the determination of dynamic modulus, $\mathrm{E}^{*}$ is still required to obtain new specifications for the use of EAFS in different fields of application to conserve Egypt's natural resources. Given the high strength of the materials and the potential employment creation benefits, the research on these materials is continuing.

\section{References}

[1] American Association of State Highway and Transportation Officials (AASHTO), 2000. Standard method of test for clay lumps and friable particles in aggregate. Test Procedure T112-00, AASHTO, Washington, D.C.

[2] AASHTO, 2002. Standard method of test for coating and stripping of bitumen-aggregate mixtures. Test Procedure T182-02, AASHTO, Washington, D.C.

[3] AASHTO, 2002. Standard method of test for resistance to degradation for Small Size Coarse aggregate by abrasion and impact in the Loss Angeles machine. Test Procedure T96-02, AASHTO, Washington, D.C.

[4] AASHTO, 2003. Standard method of test for penetration of bituminous materials. Test Procedure T49-03, AASHTO, Washington, D.C.

[5] AASHTO, 2003. Standard method of test for kinematic viscosity of asphalt (Bitumen). Test Procedure T201-03, AASHTO, Washington, D.C.

[6] AASHTO, 2003. Standard method of test for soundness of aggregate by sodium sulfate or magnesium sulfate. Test Procedure T104-03, AASHTO, Washington, D.C.

[7] AASHTO, 2004. Standard method of test for flash and fire points by Cleveland open cup. Test Procedure T48-04, AASHTO, Washington, D.C.

[8] AASHTO, 2004. Standard method of test for softening point of bitumen (ring-and-ball apparatus). Test Procedure T53-04, AASHTO, Washington, D.C.

[9] AASHTO, 2004. Standard method of test for specific gravity and absorption of coarse Aggregate.

Test Procedure T84-04, AASHTO, Washington, D.C.

[10] AASHTO, 2004. Standard method of test for specific gravity and absorption of fine Aggregate. Test Procedure T85-04, AASHTO, Washington, D.C.

[11] AASHTO, 2004. Standard Method of Test for Resistance to Plastic Flow of bituminous mixtures using Marshall Apparatus. Test Procedure T245-04, AASHTO, Washington, D.C.

[12] AASHTO, 2005. Standard method of test for theoretical max specific 
gravity and density of hot mix asphalt paving mixtures. Test Procedure T209-05, AASHTO, Washington, D.C.

[13] Asi, I. M., Qasrawi, H.Y. and Shalabi, F.I., 2007. Use of steel slag aggregate in asphalt concrete Mixes. NRC Research Press Website, cjce.nrc.ca, Canada. (Viewed on 19th September 2014)

[14] Asphalt Institute, 1997. Mix design methods. Manual Series No. 2 (MS2). Asphalt Institute Research Center, Lexington, Ky.

[15] Asphalt Institute, 2001. Superpave mix design. Series No. 2 (SP-2), Asphalt Institute Research Center, Lexington, Ky, USA.

[16] American Society for Testing and Materials (ASTM), 2007. Standard test method for density of semi-solid bituminous materials (Pycnometer Method) (ASTM D 70). ASTM, West Conshohocken, Pa, USA.

[17] ASTM, 2009. Standard test method for flat particles, elongated particles, or flat and elongated Particles in Coarse Aggregate (ASTM D 4791). ASTM, West Conshohocken, Pa, USA.

[18] Contra steel company, 2014. The chemical composition of electric arc furnace steel slag, http://www.yellowpages.com.eg/en/p rofile/contra-steel/68383 (Viewed on $14^{\text {th }}$ August 2014)

[19] Egyptian Code of Practice for urban and rural roads (ECP), 2008. Road materials and their tests (ECP-2008 part four). The Ministry of Housing, Utilities and Urban Communities, Egypt.

[20] Emery, J., 1984. Steel Slag Utilization in Asphalt Mixes. National Slag Association, MF 1861, Taken from Canadian Technical Asphalt Association Proceedings, http://www.nationalslag.org/sites/nati onalslag/files/documents/nsa_1861_s teel_slag_utilization_in_asphalt_mix es.pdf (Viewed on 13th December 2014)

[21] Fistrić, M., Strineka, A., Roskovic, R., 2010. Properties of steel slag aggregate and steel slag asphalt concrete. Institute IGH, Laboratory IGH, Zagreb, Croatia.

[22] John Emery Geotechnical Engineering Limited (JEGEL), 1993. Steel slag aggregates use in hot mix asphalt concrete.

[23] Final report prepared for the Steelmaking Slag Technical Committee, JEGEL, Toronto, Canada.

[24] Khan, Z. A., Malkawi, R.H, Al-Ofi, K.A. and Khan, N., 2002. Review of Steel Slag Utilization in Saudi Arabia. The 6th Saudi Engineering Conference, KFUPM, Dhahran.

[25] Lewis, D. W., 1982. Properties and Uses of Iron and Steel Slags. National Slag Association, MF182-6, National Institute for Transport and Road Research South Africa,http://www.nationalslag.org/si tes/nationalslag/files/documents/nsa 1826_properties_and_uses_slag.pdf (viewed on 13th December 2014)

[26] Louzi, N. 2012. Modification of Hot Asphalt Mixtures in Jordan and Syria by Using Steel Slag. Jordan Journal of Civil Engineering, Volume 6, No. 3.

[27] Mc. Daniel, R. S., 1990. Evaluation of Steel Slag Asphalt Surface Mixtures. Transport Research Board, 69th Annual Meeting, National Research Council, Washington, D.C.

[28] Norton, J. 1979. Use of steel furnace slag in bituminous mixtures. Research Report No. 78 TB-

23, Michigan Department of Transportation, Lansing, Michigan.

[29] Noureldin, A. S., and McDaniel, R., 1990. Evaluation of surface mixtures of steel slag and asphalt In Asphalt mix materials and mixtures. Transportation Research Board, National Research Council, 
Transportation Research Record, 1269: 133-149.

[30] Park, D. W., and Lee, H. S., 2002. Test Methods for Fine Aggregate Angularity Considering Resistance of Rutting. KSCE Journal of Civil Engineering, Vol. 6, pp.421-427.

[31] Shatnawi, A. S., Abdel-Jaber, M. S. and Ramadan, K. Z., 2008. Effect of Jordanian Steel Blast Furnace Slag on Asphalt Concrete Hot Mixes. Jordan Journal of Civil Engineering, Volume 2, No. 3.

[32] Tarco, V. A. S., 2000. Utilization of Electric Arc Furnace Slags in Denmark. Proceedings, Euroslag
Second European Slag Conference, Dusseldorf, p. 101.

[33] Topal, A., and Sengoz, B., 2006. Evaluations of Compacted Aggregate Resistant Test Compared with the Fine Aggregate Angularity Standards. Construction and Building Materials,pp.16.

[34] Yildirim, I. Z., and Prezzi, M., 2009. Use of Steel Slag in Subgrade Applications. Joint Transportation Research Program, FHWA/IN/JTRP2009/32, Indiana Department of Transportation and Purdue University, West Lafayette, Indiana. 